\title{
Does prey preference affect habitat choice in Antarctic seabirds?
}

\author{
David G. Ainley ${ }^{1}$, Christine A. Ribic ${ }^{2}$, William R. Fraser ${ }^{1, *}$ \\ ${ }^{1}$ Point Reyes Bird Observatory, Stinson Beach, California 94970, USA \\ ${ }^{2}$ U.S. EPA Environmental Research Laboratory, Corvallis, Oregon 97333 , USA
}

\begin{abstract}
Diet composition of the members of 2 seabird species assemblages in the Scotia-Weddell Confluence region, Antarctica, was investigated during 3 seasons/years: spring 1983, autumn 1986, and winter 1988. One assemblage frequented the pack ice and the other was present in adjacent open waters; most members of the latter species assemblage vacated the Antarctic during winter. We sought answers to 2 questions: (1) Did the 2 species assemblages depend on food webs that differed substantially; and (2) Was there a trophic basis to explain why the pack-ice assemblage did not expand into the open water left vacant by the other during winter? To test an a priori hypothesis that diet was affected by habitat, diet samples were obtained from birds encountered in 3 habitats: open water, sparse concentrations of ice, and heavy ice cover. Cluster analysis showed broad overlap in seabird diet regardless of species, habitat (ice/water mass) or year. Seabirds exploited prey largely according to ranked availability, although they appeared to choose the larger fish and crustaceans over smaller crustaceans. Myctophids in particular, but also krill and squid, were the main prey groups. Diets did not separate on the basis of predator/prey size to any appreciable degree even though a 1000 -fold difference in predator size existed. Feeding success, as indicated by fullness of stomach, of the members of the 2 species assemblages was highest when in their respective usual habitats. We conclude that open-water seabirds lack the specialized foraging behaviors required to exploit the pack-ice environment and that open waters during the winter offer much poorer feeding conditions than those of the pack ice.
\end{abstract}

\section{INTRODUCTION}

In the Southern Ocean, pack ice, a physical feature of habitat, affects the presence or absence of 2 distinct seabird assemblages; one is constrained to the pack ice and the other to the open water (Murphy 1936, Watson 1975, Fraser \& Ainley 1986, Ainley, Ribic, Fraser \& Spear unpubl. data). The pack-ice assemblage comprises emperor and Adélie penguin, snow and Antarctic petrel and Antarctic fulmar, and that of open water comprises king and chinstrap penguin, Kerguelen, blue and cape petrel, Antarctic prion and southern giant fulmar (Ainley et al. unpubl. data). It is not yet known whether physical or biological characteristics of the ice or of the open water restrict or attract these assemblages to respective habitats. Griffiths (1983) thought that wind pattern, a physical feature that differs over the ice compared to the open sea, as well as

\footnotetext{
- Present address: Department of Oceanography, Old Dominion University, Norfolk, Virginia 23529, USA
}

the paucity of open water within pack-ice areas, exclude the open-water birds from the ice. This reasoning, however, does not account for differences in penguin species between the 2 habitats, although the same factor does not necessarily have to explain the presence or absence of all species within particular assemblages (Wiens 1989, p. 295).

This study investigated seabirds of the open water and adjacent pack ice within the confluence of the Scotia and Weddell Seas to determine the degree to which diet, a biological feature, might differ by habitat. This analysis is part of a larger study in which we had learned that differences in prey availability may exist between pack-ice covered and open waters in this area (Ainley et a]. 1986), as well as waters in which the depth of the chlorophyll maximum differed (Ainley et al. 1991). Further, we had found that when seasonally resident species had departed the open waters the year-round residents, which comprise the pack-ice assemblage, did not invade the vacated open-water habitat (Ainley et al. unpubl. data). This phenomenon is analogous to that of the resident and seasonal mig- 
rant landbirds of the tropics, where the habitat of the migrants is also left vacant by the resident species during the absence of the migrants (Keast \& Morton 1980). For this paper we used the diets of the seabird assemblages to investigate whether there is a trophic basis underlying habitat preference in Southern Ocean seabirds, and whether that would help to explain the dichotomy in habitat use by seasonal and year-round residents or by pack-ice and open-water species. Such an analysis, relating marine habitat preference to diet, has not to our knowledge been previously attempted.

\section{METHODS}

This study was part of the program, Antarctic Marine Ecosystem Research in the Ice Edge Zone (AMERIEZ), which investigated marine ecology at all trophic levels, including trophodynamic rates and processes. AMERIEZ carried out its work in the marginal ice zone of the confluence region of the Scotia and Weddell seas, comparing phenomena among spring (November 1983), autumn (March 1986), and winter (July-August 1988). See Ainley et al. (1991) for a map of the study region. Simultaneous investigations of physical oceanography determined the type of water in which sampling took place (Tables 1 \& 2; Husby \& Meunch 1988, Husby et al. 1989, Meunch et al. 1992), and investigations of micronekton determined relative prey availability (Lancraft et al. 1989, 1991). Ainley \& Sullivan $(1984,1989)$ and Sullivan \& Ainley (1987) describe each cruise in detail.

We collected food samples mostly by shooting birds attracted to us (in a small boat) using cod liver oil as bait; in addition, all penguin samples and some from aerial species were obtained using the water off-loading technique in which live birds are netted and their stomachs pumped (Wilson 1984). The fact that we took advantage of the olfactory senses of seabirds by attracting them using slicks of cod liver oil (see Jouventin \& Robin 1984) may have brought some individuals from a habitat nearby but different from the one we thought we were sampling. This would potentially diminish somewhat, and make more conservative, the power of our analyses. In that we used the oil only to concentrate and bring into range those birds in the local area meant that this potential effect would be minimal; indeed, most of our collections lasted no more than an hour from launch to retrieval of the small boat (i.e. 20 to 40 min positioned at the slick). Thus, the birds sampled would not have come from far away.

Our intent from the outset was to make intra- and interspecific comparisons of species diet among different habitats, particularly open-water, ice edge (sparse ice concentration) and interior (heavy concentration) pack ice. Thus, when we knew that an oceanographic station was to be held in one or another habitat we scheduled a collecting trip. The scheduling took place well before we arrived on station. The choice of stations was not opportunistic, but was built into the cruise plan. We did not collect birds from feeding flocks (we saw none; they are relatively rare in the Antarctic: see Ainley \& Boekelheide 1983). At each sampling site we attempted to obtain 4 to 5 examples from each of the avian species present, with the exception of southern giant fulmars (see Table 1 for scientific names), which only eat carrion and at sea often have empty stomachs (Ainley et al. 1984, 1991). We therefore did not collect

Table 1. Scientific and common names of birds and translations of bird-name codes used in subsequent tables; capitalizations of letters in the common names indicate derivation of the codes (this is only a partial list of codes used in our seabird studies)

\begin{tabular}{|lll|}
\hline PENE & PENguin, Emperor & Aptenodytes forsteri \\
PENA & PENguin, Adèlie & Pygoscelis adeliae \\
PENC & PENguin, Chinstrap & Pygoscelis antarctica \\
FUSG & FUlmar, Southern Giant & Macronectes giganteus \\
FUAN & FUlmar, ANtarctic & Fulmarus glacialoides \\
PETH & PETrel, wHite-headed & Procellaria aequinoctialis \\
PEAN & PEtrel, ANtarctic & Thalassoica antarctica \\
PETC & PETrel, Cape & Daption capense \\
PEBL & PETrel, Snow & Pagodroma nivea \\
PRAN & PEtrel, BLue & Halobaena caerulea \\
PTKG & PRion, ANtarctic & Pachyptila desolata \\
DIPE & PeTrel, KerGuelen & Pterodroma brevirostris \\
STBB & DIving PEtrel & Pelecanoides spp. \\
STWI & STorm-petrel, Black-Bellied & Fregetta tropica \\
SKMA & STorm-petrel, Wllson's & Oceanites oceanicus \\
GUDO & SKua, MAccormick's (or South Polar) & Catharacta maccormicki \\
TEAN & GUH, DOminican (or Kelp) & Larus dominicanus \\
TEAR & TErn, ANtarctic & Sterna vitatta \\
& TErn, ARctic & Sterna paradisaea \\
\hline
\end{tabular}


additional specimens of this species. We conducted collections as close to day break as possible so that prey would be least digested, as most species feed during crepuscular periods or darkness (Ainley et al. 1984). We obtained 779 samples during the 3 cruises, and achieved broad species representation in various habitats defined by ice concentration and water mass (Table 2).

We sampled birds within 3 habitats defined by ice, open water, marginal ice (1-3 oktas) and interior pack (>3 oktas). An okta equals one-eighth of the surface area of the ocean as viewed from the flying bridge; it is a standard, international measure of ice concentration. Owing to the rapid appearance and disappearance of ice during 1988 and the consequent ephemeral existence of sparse ice concentrations (Ainley et al. unpubl. data), ice of 4 oktas was included in the marginal category during that year only.

Details on how stomach samples were sorted, weighed and measured are contained in Ainley et al. (1991). In short, we estimated original body mass and length of partially digested prey items using regressions against hard parts such as otoliths, cephalopod beaks and crustacean exoskeletons. We included only those otoliths and beaks that showed no signs of digestion. On the basis of the size-mass regressions for prey and the number of respective prey in each stomach, we reconstituted the mass of stomach contents for each bird (cf. Adams \& Klages 1987) and, on the basis of respective samples, compared prey size among predators.

Our reconstituted mass rarely exceeded $25 \%$ of body mass: once for Antarctic fulmar, twice for Antarctic petrel, blue petrel, Antarctic prion and Wilson's stormpetrel, and 4 times for snow petrel. At least for procellarids (which include these latter species), when flying long distances from feeding grounds to provision young (which was not the case in the present study), a maximum meal size of about $25 \%$ of body mass is reasonable (Ricklefs et al. 1985, Croxall et al. 1988). Accordingly, we reduced the few, overly large values to $25 \%$ of body mass, a procedure that had virtually no effect on results given our large sample sizes. In reality, seabirds do at times gorge themselves to the point of not being able to fly (Ainley pers. obs.), and as long as these birds do not have to transport food to chicks, there is little reason why consuming that much food would be maladaptive.

Duffy \& Jackson (1986), Croxall et al. (1988), and Klages et al. (1990) discussed the problems inherent in comparisons among stomach contents mass using samples collected at sea, regurgitations from adults feeding chicks, and reconstituted vs actual mass. In light of their comments, the modifications and the

Table 2. Sample sizes followed by proportion of empty stomachs in parentheses, among seabirds collected within various habitats in the southern Scotia and northern Weddell Seas and the Scotia-Weddell Confluence, 1983-1988. Three habitats were defined by ice concentration: open water; marginal ice (1-3 oktas); and interior pack ( $>3$ oktas). 1 okta equals one-eighth of the surface area of the ocean as viewed from the flying bridge. Age of ice: new, $\leqslant 1 w_{k}$; old, $>1$ wk

\begin{tabular}{|c|c|c|c|c|c|c|c|c|c|c|c|c|}
\hline \multirow{4}{*}{$\begin{array}{l}\text { Bird } \\
\text { species }\end{array}$} & \multicolumn{4}{|c|}{1983} & \multicolumn{3}{|c|}{1986} & \multicolumn{5}{|c|}{1988} \\
\hline & \multirow[t]{3}{*}{ Scotia $^{\mathrm{d}}$} & \multicolumn{3}{|c|}{ Confluence (ice cover) } & \multicolumn{3}{|c|}{ Weddell (ice cover) } & \multirow[t]{3}{*}{ Scotia ${ }^{a}$} & \multicolumn{4}{|c|}{ Confluence (ice cover) } \\
\hline & & Open & $<1-3$ & $4-8$ & Open & $<1-3$ & $4-8$ & & Open & $<1-4^{b}$ & & -8 \\
\hline & & & & (Old) & & & (Old) & & & & New & Old \\
\hline PENE & - & - & - & - & - & - & 18 & - & - & - & - & 8 \\
\hline PENA & - & - & - & - & - & 2 & 9 & - & - & - & - & $29(17)$ \\
\hline FUSG & - & $2(50)$ & - & - & - & 1 & - & 1 & - & - & - & - \\
\hline PETH & 4 & 7 & 1 & - & - & - & - & - & - & - & - & - \\
\hline FUAN & 4 & $9(11)$ & 9 & $11(64)$ & $11(27)$ & $8(38)$ & - & 5 & - & 5 & $6(17)$ & - \\
\hline PETC & $4(25)$ & $26-15)$ & 8 & $11(9)$ & $12(42)$ & 3 & 1 & 2 & - & $7(14)$ & $4(75)$ & - \\
\hline PEAN & - & - & 8 & 11 & $38(3)$ & $14(29)$ & - & 16 & 1 & 8 & 19 & 2 \\
\hline PETS & 1 & 1 & 26 & $41(15)$ & - & 9 & 33 & 18 & $12(8)$ & 5 & 20 & $15(7)$ \\
\hline PEBL & 4 & 22 & - & 3 & 17 & - & - & 7 & - & 3 & 7 & - \\
\hline PRAN & 4 & 25 & 8 & $14(21$ & $10(10)$ & 5 & - & - & - & - & - & - \\
\hline PTKG & - & - & - & - & $21(5)$ & 3 & - & 5 & - & - & - & - \\
\hline DIPE & - & $1(100)$ & - & - & - & - & - & $2(100)$ & - & $1(100)$ & - & - \\
\hline STBB & - & 5 & 1 & - & - & - & - & - & - & - & - & - \\
\hline STWI & 4 & $21(14)$ & 11 & $10(70)$ & $7(43)$ & 8 & - & - & - & - & - & - \\
\hline GUDO & - & - & - & - & - & - & - & 1 & - & - & - & - \\
\hline TEAR & - & - & 9 & 1 & $2(100)$ & $4(25)$ & 6 & - & - & - & - & - \\
\hline TEAN & - & - & - & - & - & - & $7(14)$ & - & - & - & - & - \\
\hline
\end{tabular}


mean stomach masses we calculated were verified by reviewing published results with the maximum values measured in this study (Table 3). The comparison between the 2 sets of values revealed equivalent results, with 1 explainable exception. The mean reconstituted contents mass for emperor penguin was 2 times higher than mass measured elsewhere. The latter published values, however, were from emperor penguins that had been sampled after they had walked across $50 \mathrm{~km}$ or more of sea ice and, thus, had fasted for several days during the trip. Croxall \& Lishman (1987) state that penguins often carry food loads of at least $20 \%$ of body mass, which would seem to be a minimum considering what aerial species can carry. This value $(20 \%)$ is equivalent to our mean reconstituted mass for the emperor penguin.

Using the diet by percent mass composition and Morisita's Index (Horn 1966), we measured diet overlap among species from different habitats and years. We chose an overlap index value of $>0.844$ to denote diet similarity $(1.000$ equals complete overlap and 0.000 equals no overlap) as explained in Ainley et al. (1984, 1991) and Diamond (1984). Morisita's Index was used in a cluster analysis with average-linkagebetween-groups as the algorithm (Seber 1984; SPSS $\mathrm{PC}+$ Cluster, see Norusis 1986) to determine the number of similar groups that existed within 59 species/habitat/year combinations. Morisita's Index fulfills the criteria of a similarity index that can be used in a clustering algorithm (Kaufman \& Rousseeuw 1990). There were 77 combinations but we excluded those based on 4 or fewer stomach samples, thus reducing the total to 59. The latter total included none where all the samples of any species/habitat/year combination were from only 1 collecting site. The cluster analysis is presented as an icicle plot in the 'Results'. To estimate diet diversity, the Shannon Index was calculated (Magurran 1988).

We compared feeding success using 2 methods. The first method used was an ANOVA comparison of body mass by season for each species. This was a measure of body fat levels, assuming that fat levels indicate foraging efficiency (i.e. fatter birds more successful). The second, more satisfactory and direct method to assess relative feeding success, compared the mean masses of reconstituted stomach contents as a function of the habitat in which the stomach samples were collected and whether that habitat was the one preferred or avoided by respective species. Preferred means the ice concentration (open water, sparse or heavy ice) in which the species is most dense, and vice versa for avoided (Ainley et al. unpubl, data). Using ANOVA we compared mean stomach contents masses among species' preferred and least preferred habitats, while controlling for species. In all ANOVA analyses, we used the log-transformation to satisfy the normality assumption.

We determined whether the size-frequency distributions of prey taken by different predators were different using log-linear models with adjusted standardized residuals (Feinberg 1980). For small sample sizes, the $p$-values for the $\chi^{2}$ were calculated using StatXact version 2.02 (Mehta \& Patel 1992). The null hypothesis tested was that the distribution of prey sizes in a predator's diet was a multinomial distribution with the proba. bility of each prey size class independent of the predator. All models and residuals were fit using SPSS PC+ Hiloglinear (Norusis 1986). Finally, we used Spearman rank correlations (Conover 1980) to compare diet composition to (1) predator size and (2) the proportion of

Table 3. A comparison of mean $(\overline{\mathrm{x}})$ and maximum values between actual and reconstituted stomach contents weights ( $\mathrm{g}$ ) in this study and actual values published in the literature

\begin{tabular}{|c|c|c|c|c|c|c|}
\hline \multirow[t]{3}{*}{ Species } & \multirow{2}{*}{\multicolumn{2}{|c|}{$\begin{array}{c}\text { Published values } \\
\text { Actual }\end{array}$}} & \multirow{2}{*}{\multicolumn{4}{|c|}{ This study }} \\
\hline & & & & & & \\
\hline & $\overline{\mathrm{x}}$ & $\operatorname{Max}$ & $\overline{\mathrm{x}}$ & Max & $\vec{x}$ & $\operatorname{Max}$ \\
\hline PENE & $1334^{1}, 1335^{2}, 2820^{3}$ & $4580^{1}$ & 83 & 490 & 6074 & 25800 \\
\hline PENA & $251^{4}, 300^{5}, 350^{6}, 634^{7}$ & $1020^{7}$ & 63 & 163 & 16 & 261 \\
\hline FUAN & $15^{4}$ & $54^{9}$ & 17 & 58 & 35 & 161 \\
\hline PEAN & $10^{8}, 51^{9}, 31^{10}, 150^{11}$ & $114^{9}$ & 26 & 117 & 29 & 582 \\
\hline PETC & $11^{4}$ & $41^{4}$ & 9 & 37 & 7 & 74 \\
\hline PETS & $25^{4}$ & $56^{4}$ & 10 & 39 & 31 & 219 \\
\hline PEBL & $11^{12}$ & & 8 & 33 & 15 & 97 \\
\hline PRAN & $9^{12} \cdot 14^{13}$ & $52^{13}$ & 5 & 10 & 11 & 64 \\
\hline STWI & $3^{4}, 2^{14}$ & $6^{14}$ & 2 & 8 & 2 & 15 \\
\hline \multicolumn{7}{|c|}{$\begin{array}{l}\text { Sources: }{ }^{1} \text { Gales et al. (1990), }{ }^{2} \text { Klages (1989), }{ }^{3} \text { Offredo \& Ridoux (1986), }{ }^{4} \text { Ridoux \& Offredo (1989), }{ }^{5} \text { Lishman (1985), } \\
6 \text { Volkman et al. (1980), }{ }^{7} \text { Emision (1968), }{ }^{8} \text { Griffiths (1983), }{ }^{9} \text { Klages et al. (1990), }{ }^{10} \text { Montague (1984), }{ }^{11} \text { Mehlum in Klages et } \\
\text { al. (1990), }{ }^{12} \text { Prince (1980), }{ }^{13} \text { Gartshore et al. (1988) (another but similar species), }{ }^{14} \text { Croxall et al. (1988) } \\
\text { - These weights included stomach oil; oil not included in measurements for any of the other studies including the present one }\end{array}$} \\
\hline
\end{tabular}


various prey species in net trawls. The latter supposedly represented the community composition among the micronekton in the upper $100 \mathrm{~m}$ of the water column. These AMERIEZ data were provided by Lancraft et al. (1989, 1991), who conducted trawls contemporary with our bird collections. Those authors' highest to lowest ranking of micronekton species by biomass was as follows: Euphausia superba, Electrona antarctica, Salpa thompsoni, Gymnoscopelus braueri, Thysanoessa macrura, and tied at the lower end of the scale, Notolepis coatsi, Euphausia triacantha, Cyllopus lucasii and other rare forms such as Pasiphaea scotia.

\section{RESULTS}

\section{Diets}

Regardless of whether samples were taken in the Scotia Sea or Weddell Sea, the Scotia-Weddell Confluence, or in the open or ice-covered waters of these areas, diet diversity was low (Fig. 1). Diets were domi-

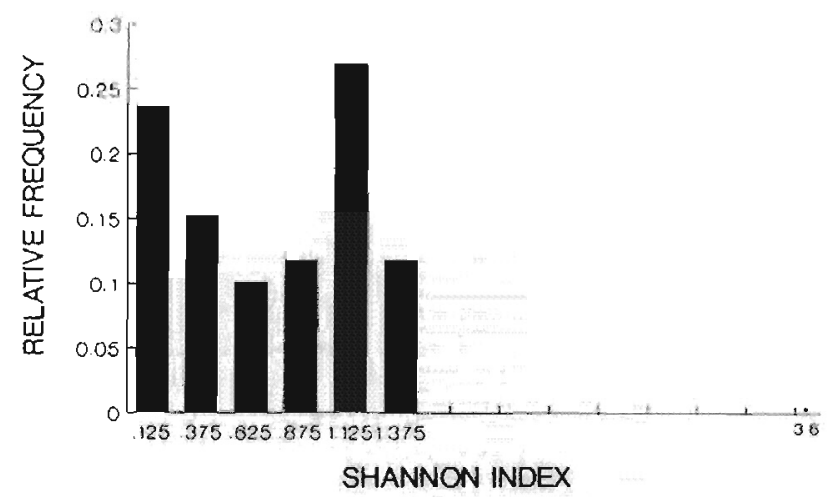

Fig. 1. Histogram of the Shannon Index for 59 species/habitat/ year combinations for AMERIEZ seabird diet data. Maximum diversity is indicated by the dot at the right end of the $x$-axis; numbers under the bars are the midpoint values

nated by the euphausiid Euphausia superba; the amphipods Vibilia antarctica and Cylopus lucasii; the myctophid fishes Electrona antarctica, Protomycytophum bolini, and Gymnoscopelus braueri; the squid Galiteuthis glacialis, and the salp Salpa thompsoni (Table 4). Salps were more prominent in the ocean (trawl data) and in diets during 1983 (spring) than in other seasons or years (see Fig. 2; Lancraft et al. 1991). E. superba was more prominent during 1988 (autumn). Some predator-specific differences were apparent as well. For instance, emperor penguins fed more heavily on squid, snow petrels more on myctophids, and prions more on crustaceans than did other birds. Another obvious pattern was that diet composition determined by number of items resulted in a dominance of crusta- ceans, especially E. superba, but on the basis of mass, squid and fish, especially E. antarctica, predominated. The importance of crustaceans was thus reduced considerably

One major diet group was evident (Fig. 2, Table 4): 36 of the 59 avian species diet/habitat/season combinations were dominated by Electrona antarctica. Of the remaining 23 combinations, 9 were similar or different owing to various groupings of E. antarctica with 2 squid species, other fish species or large (non krill) crustaceans; close similarity among 2 combinations was the consequence of krill being the major prey species; 1 combination was distinctive owing to concentration of 1 fish species (Notolepis coatsi): and the remainder comprised various groupings of 4 squid species.

In the 23 divergent diet combinations, only 4 were from 1988 and all differed as a result of one squid species or another. The 2 krill-dominated diets were from 1986, when sampling was done entirely in Weddell Sea water. Four of the divergent diet combinations came from birds collected over unmixed Scotia Sea water (in 1983). All but 6 of the exclusively Electrona antarctica diets occurred in ice-covered waters. Otherwise, other than the predominance of $E$. antarctica there was no consistent pattern that set any assemblage of predators apart from others on the basis of diet. Only 1 predator species, emperor penguin, had a diet (of squid) that was consistent among years. In both years the penguin was sampled in heavy ice, once in Weddell Sea water and the other in confluence waters of the Scotia-Weddell Seas.

To the abundance ranking of micronekton species within the upper $100 \mathrm{~m}$ of the water column (from Lancraft et al. 1989, 1991; see 'Methods'), we compared rankings of prey in seabird diets on the basis of both mass and numerical composition. Ranking compared favorably between trawls and diet for several avian species (Table 5), especially for those open-water birds that vacate the Antarctic during winter.

\section{Prey size in relation to predator size}

Predator size ranged from the $35 \mathrm{~kg}$ emperor penguin, with a bill length of $15 \mathrm{~cm}$, to the $0.04 \mathrm{~kg}$ Wilson's stormpetrel, with a bill length of $1.2 \mathrm{~cm}$ (Fig. 3). The proportion of squid decreased and that of fish increased in diets as predator size decreased; the proportion of small crustaceans showed no trend (squid, Spearman $\mathrm{r}=$ $0.959, p<0.01$; fish and large crustaceans, $r=-0.736$, $p<0.01$; small crustaceans, $r=-0.189, p<0.3 ; \mathrm{df}=13$ ). The ordering of the predators in Fig. 3 , on the basis of size, did not reveal any pattern affected by habitat.

We also examined the size-frequency distributions of the prey taken by the different predators to determine 
the degree to which predator size may have affected diet composition. We confined this analysis to the more numerous prey species in individual predators' diets. The size distribution of krill, the smallest of the prey species analyzed, differed among the predators diets and thus we rejected our null hypothesis $\left(\chi^{2}=9881.3\right.$, $\left.G^{2}=8923.6, \mathrm{df}=55, \mathrm{p}<0.001\right)$. From residual analysis, Adélie penguins ate more krill of the smaller size classes (2 and 3, numbering classes consecutively smallest on the left to largest on the right; Fig. 4). All the other predators compared ate fewer of prey sizes 2 and 3 than expected under the multinomial null hypothesis. Emperor penguin, blue petrel, Antarctic prion and Wilson's storm-petrel ate greater numbers of prey sizes 1 and 4; Antarctic fulmar, Antarctic petrel and cape petrel ate more size classes 1 and 4 to 6 ; snow petrel and Arctic tern ate more of classes 1, 5 and 6 ; white-chinned petrel ate more of class 5, and Kerguelen petrel ate more of classes 4 to 6 . Thus, there was no consistent trend related to predator size. The krill eaten by the 3 smaller predators (Fig. 3: blue petrel, Antarctic prion and Wilson's storm-petrel) were small (but, note, the small Arctic tem ate large krill), but so were those eaten by the 2 largest predators (Adélie and emperor penguin).

The next largest prey consumed in quantity, the myctophid Electrona antarctica, also showed measurable size differentiation among predators $\left(\chi^{2}=145.7\right.$, $G^{2}=151.6, \mathrm{df}=49, \mathrm{p}<0.001$; Fig. 5). Prey sizefrequency distributions for emperor penguin, Kerguelen petrel and Antarctic prion did not deviate from the multinomial model. Antarctic fulmars ate more in the larger size classes (classes 6,7 and 8); Antarctic petrel ate few of the smallest size class (1) and ate more of size class 6; cape petrel ate more size class 3; snow petrel ate more of size classes 1 to 3 ; and blue petrel ate

\section{DIET OVERLAP : MORISITA'S INDEX}
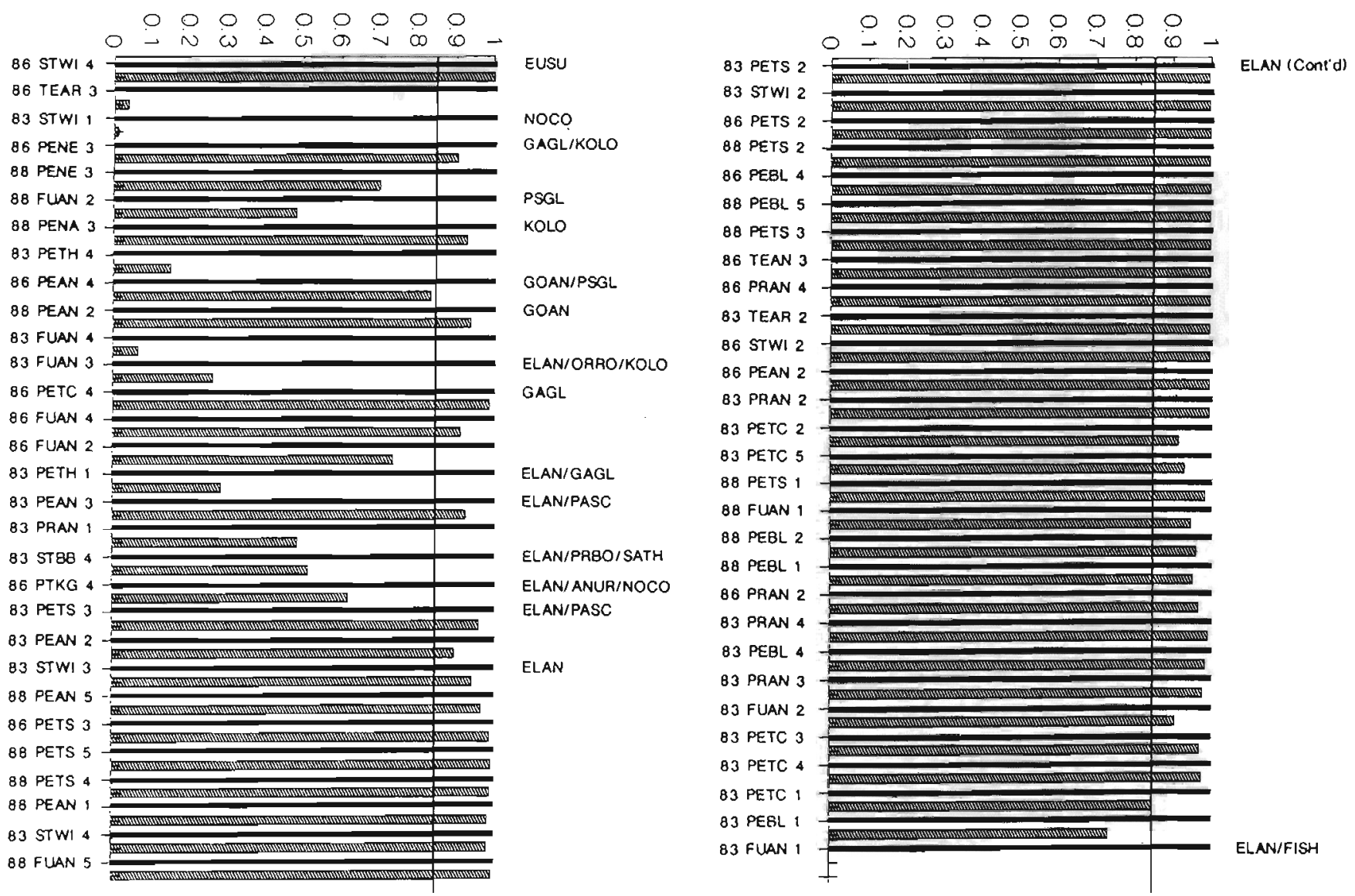

Fig. 2. Cluster diagram showing similarities in the diets of seabirds in different habitats. Bird species names are explained in Table 1 . Each name is preceded by the year in which collection was made $(83=1983,86=1986$ and $88=1988)$ and is followed by a number that denotes habitat ( $1=$ open water, $2=$ sparse ice, $3=$ heavy ice; see Table 2 ). Prey species names are composed of the first 2 letters of generic and specific names (see Table 3). The line running through the diagram indicates the level at which diet is considered to be similar on the basis of prey species overlap (0.84, see 'Methods') 
Table 4. A summary of diets for all species regardless of habitat or year in which samples were obtained; values are percent compositions by number and by mass, and percent frequency of occurrence

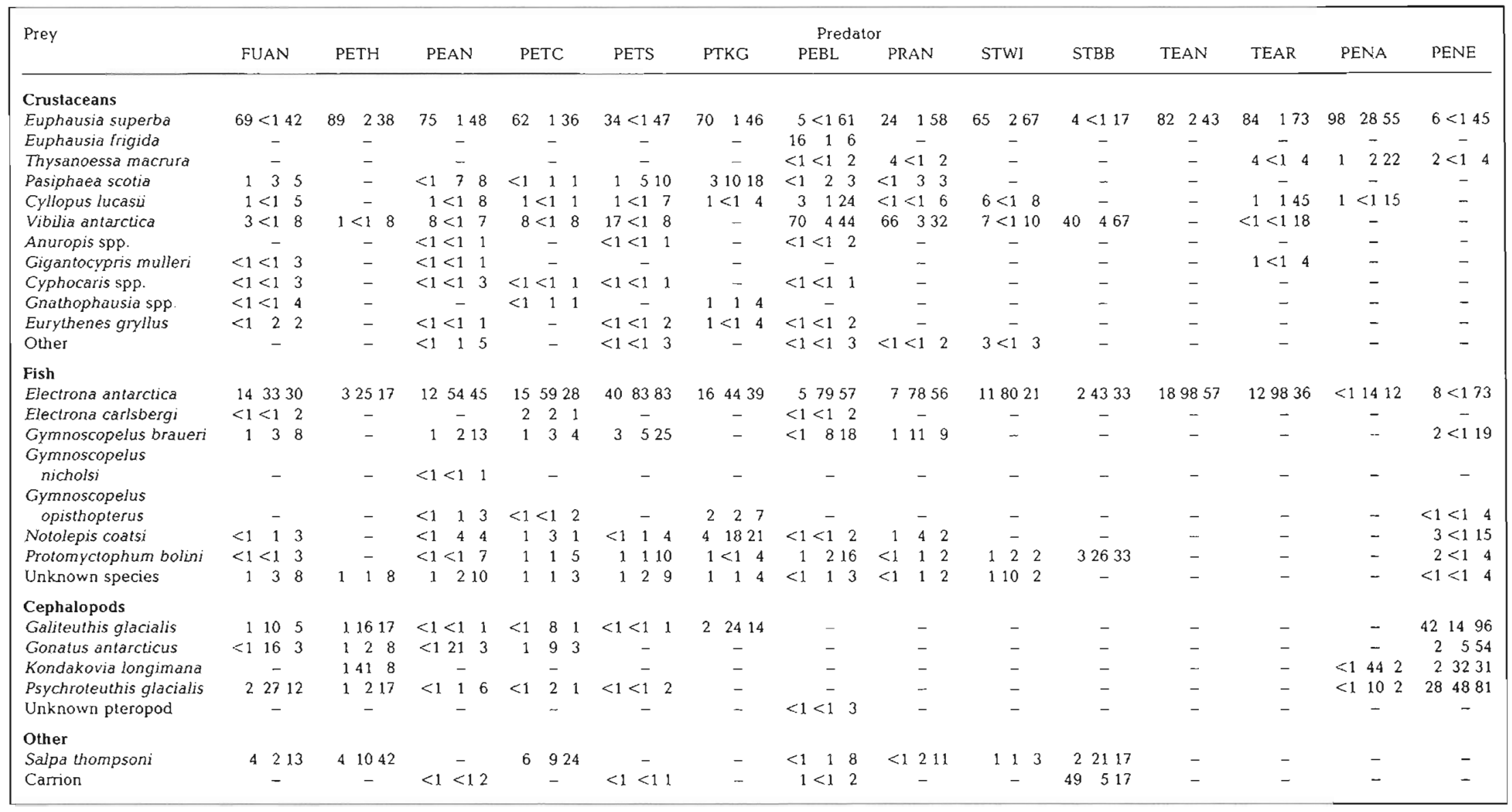


Table 5. Values of Spearman's $r$ for comparisons of micronekton ranked by abundance in trawls (composition by biomass; Lancraft et al. 1989, 1991) and in seabird diets (composition by mass and number); underlined species are year-round residents of the pack ice or adjacent open water (Ainley et al. unpubl. data)

\begin{tabular}{|c|c|c|c|c|c|c|c|c|c|c|c|}
\hline & $\underline{\text { FUAN }}$ & PETH & PEAN & PETC & PETS & $\begin{array}{l}\text { Birds } \\
\text { PTKG }\end{array}$ & PEBL & $\underline{\text { PRAN }}$ & STWI & TEAR & PENA \\
\hline Mass & 0.12 & $0.88^{8}$ & -0.11 & 0.52 & -0.04 & 0.12 & 0.35 & 0.25 & $0.80^{\mathrm{a}}$ & 0.45 & 0.63 \\
\hline Number & $0.74^{a}$ & $0.89^{a}$ & 0.48 & $0.83^{a}$ & 0.45 & 0.29 & 0.61 & $0.70^{\mathrm{a}}$ & $0.71^{B}$ & 0.63 & 0.34 \\
\hline \multicolumn{12}{|c|}{ "p $<<0.05, \mathrm{df}=7$} \\
\hline
\end{tabular}

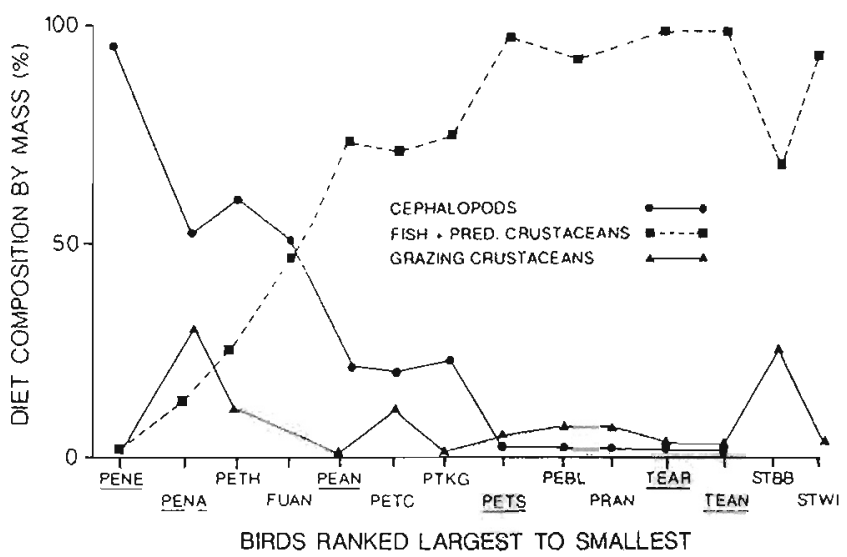

Fig. 3. The proportion of squid, fish (plus large, predatory crustaceans) and small crustaceans in seabird diets as a function of predator size ranked largest to smallest; see Table 1 for explanation of bird species' names. Underlining indicates pack-ice species more of size class 8. Given the range of species' size, this pattern, too, seemed unrelated to predator size and more related to the habitat in which the prey were captured (see 'Discussion').

If there is any basis to prey size selection as a function of predator size, it should be most obvious in the prey that can attain large enough size to test a predator's capabilities in prey handling (Fig. 6). Other than the very large emperor penguin, which for some squid species took the larger individuals, prey size differences were either non-existent or were again dependent on habitat. In the case of the squid Psychroteuthis glacialis $\left(\chi^{2}=14.2, G^{2}=14.0, p=0.03, \mathrm{df}=6\right)$, emperor penguins ate more of size class 6 (the largest), and the other predators more of size class 2 (the smaller class). For Galiteuthis glacialis $\left(\chi^{2}=2.2, p=0.74, G^{2}=\right.$ 2.96, $\mathrm{p}=0.71, \mathrm{df}=4 \mathrm{l}$, the null hypothesis was not rejected. Only the very largest squid taken by the

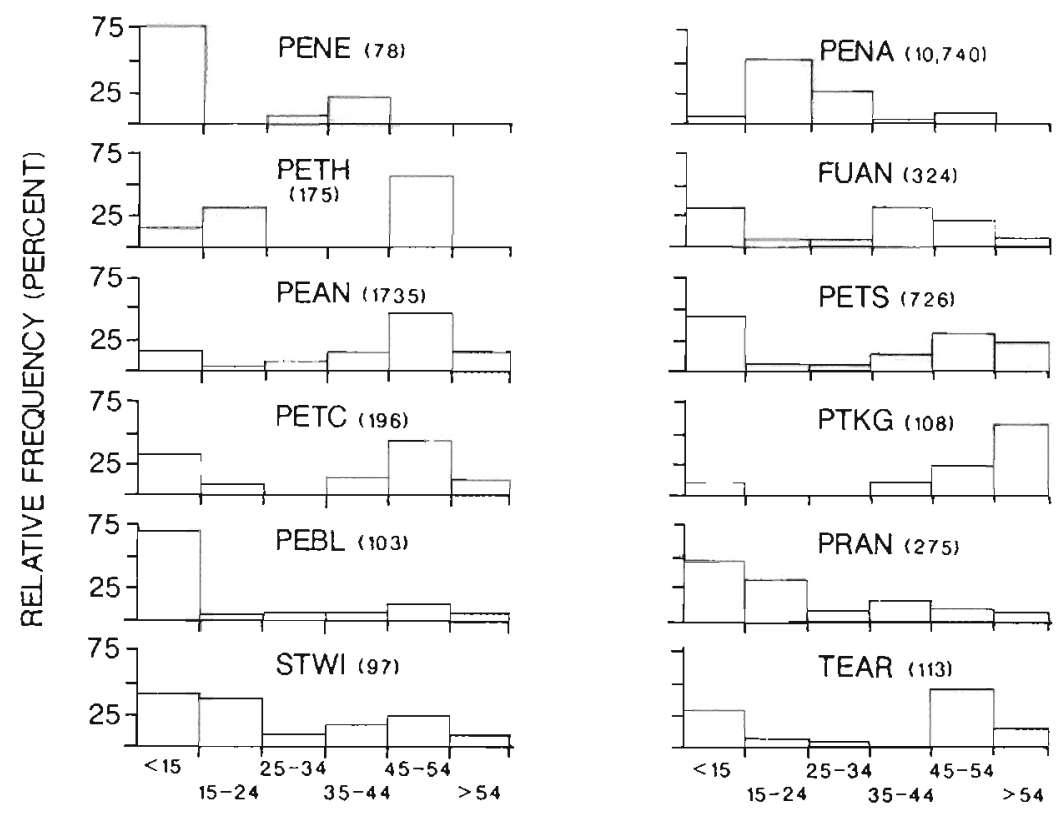

Euphausia superba Length ( $\mathrm{mm}$ )
Fig. 4. Euphausia superba. A comparison of relative size-frequency distribution for krill in the diets of seabird predators; see Table 1 for explanation of bird species names. (n): number of samples 
Fig. 5. Electrona antarctica. A comparison of relative size-frequency distribution for $E$ antarclica in the diets of seabird predators; see Table 1 for explanation of bird species' names. (n): number of samples

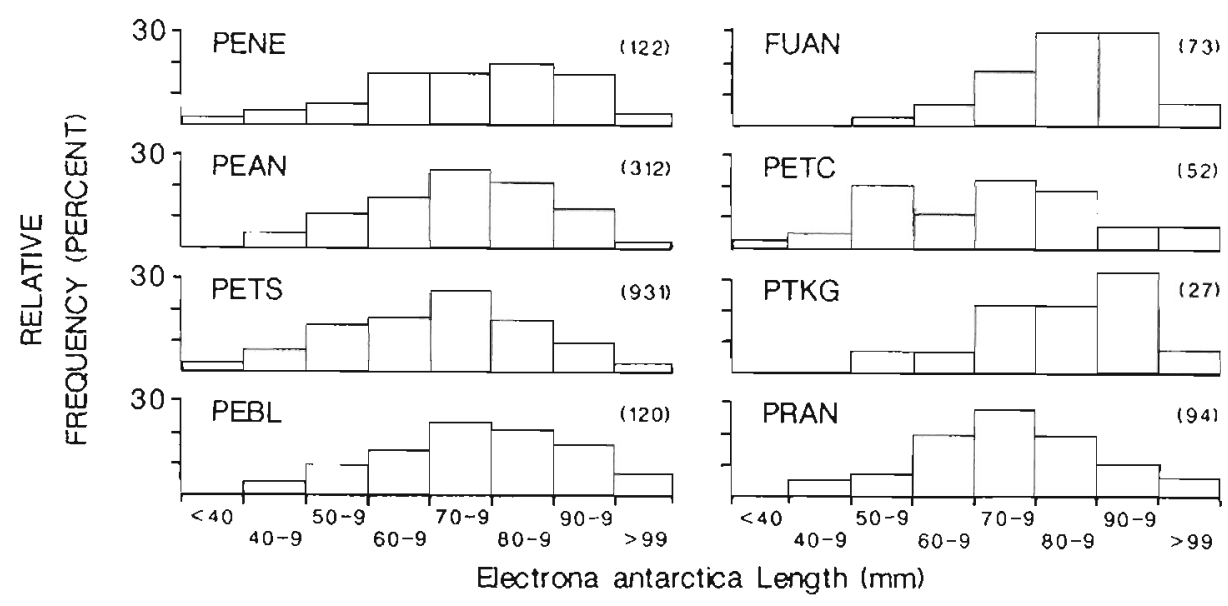

emperor penguins were larger than those taken by any of the other predators, and in fact, were larger than the other predators themselves (except in some instances the Adélie penguin)! For pasiphaeids, the null hypothesis was not rejected $\left(\chi^{2}=11.7, p=0.101, G^{2}=\right.$ 18.47, $p=0.08$, df $=7$ ). Finally, for the larger fish
Notolepis coatsi, the null hypothesis was rejected $\left(\chi^{2}=\right.$ 21.4, $G^{2}=26.3, \mathrm{df}=4, \mathrm{p}<0.001$ ). The large emperor penguin ate increased numbers of small individuals (classes 2) of this fish, while the other, smaller predators ate increased numbers of both small and large fish (classes 1 and 5).
Fig. 6. A comparison of the size frequency distributions for various larger micronekton in the diets of seabird predators; see Table 1 for explanation of bird species' names. (n): number of samples
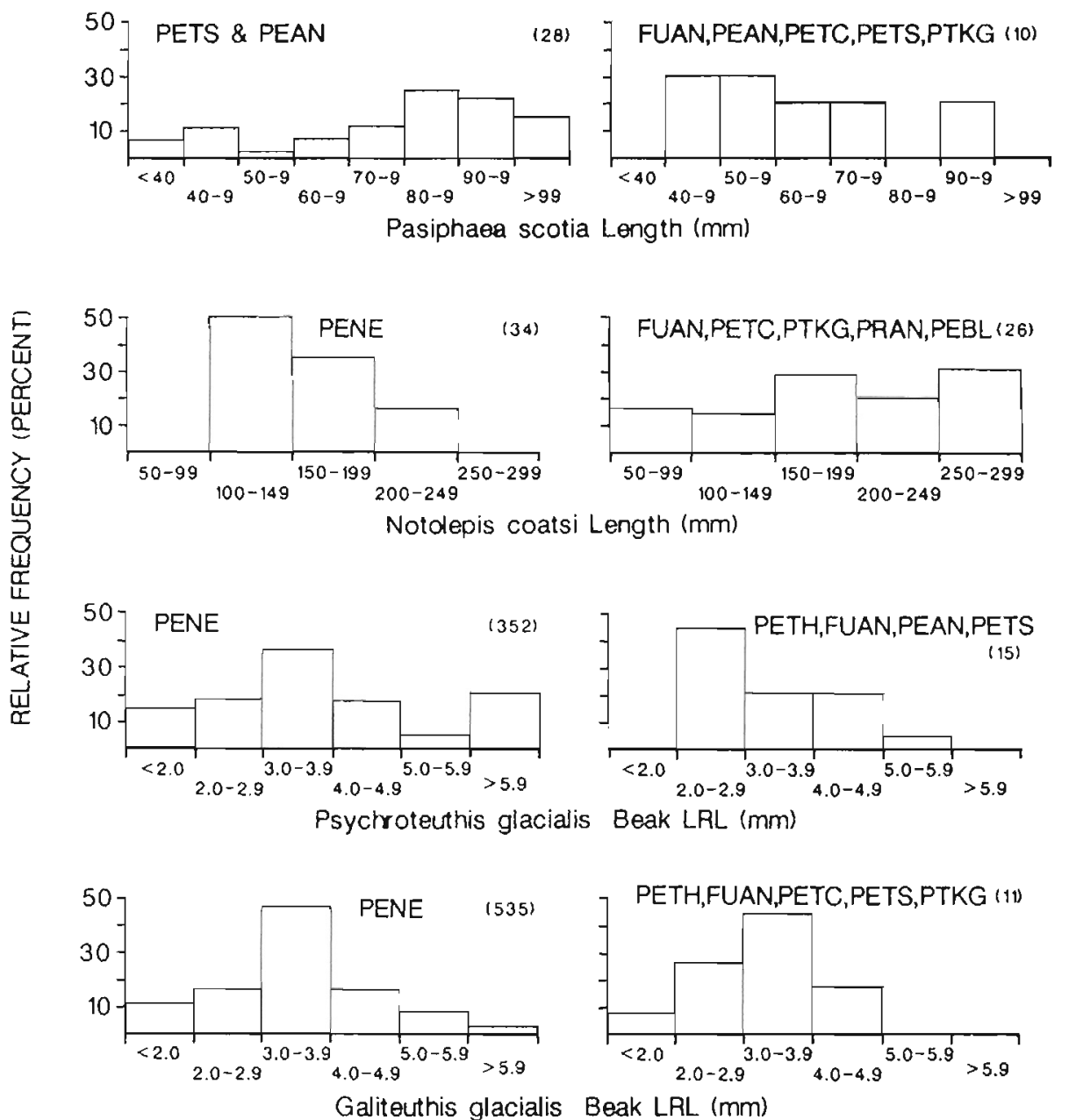


\section{Feeding success}

A measure of feeding success is the fat level attained by birds because they store excess nutrients as subdermal and mesenteric fat. As fat level increases so does body mass. Controlling for species, lowest body mass, even after factoring out stomach contents mass, was attained during spring $(F=15.61$, df $=2,9 ; p<0.001$;
Fig. 7). On an individual basis, only Kerguelen petrel showed no seasonal trend in mass $(F=0.54$, df $=1,2$, $\mathrm{p}=0.47$; after $\log$ transformation, the only sample in which this was required). The trend for Antarctic petrel was just barely significant $(F=2.98$, df $=1,2$; $\mathrm{p}=$ $0.555)$, but for all others it was marked $(F>6.90$, $\mathrm{p}<0.002$ ).

The primary measurement of feeding success used
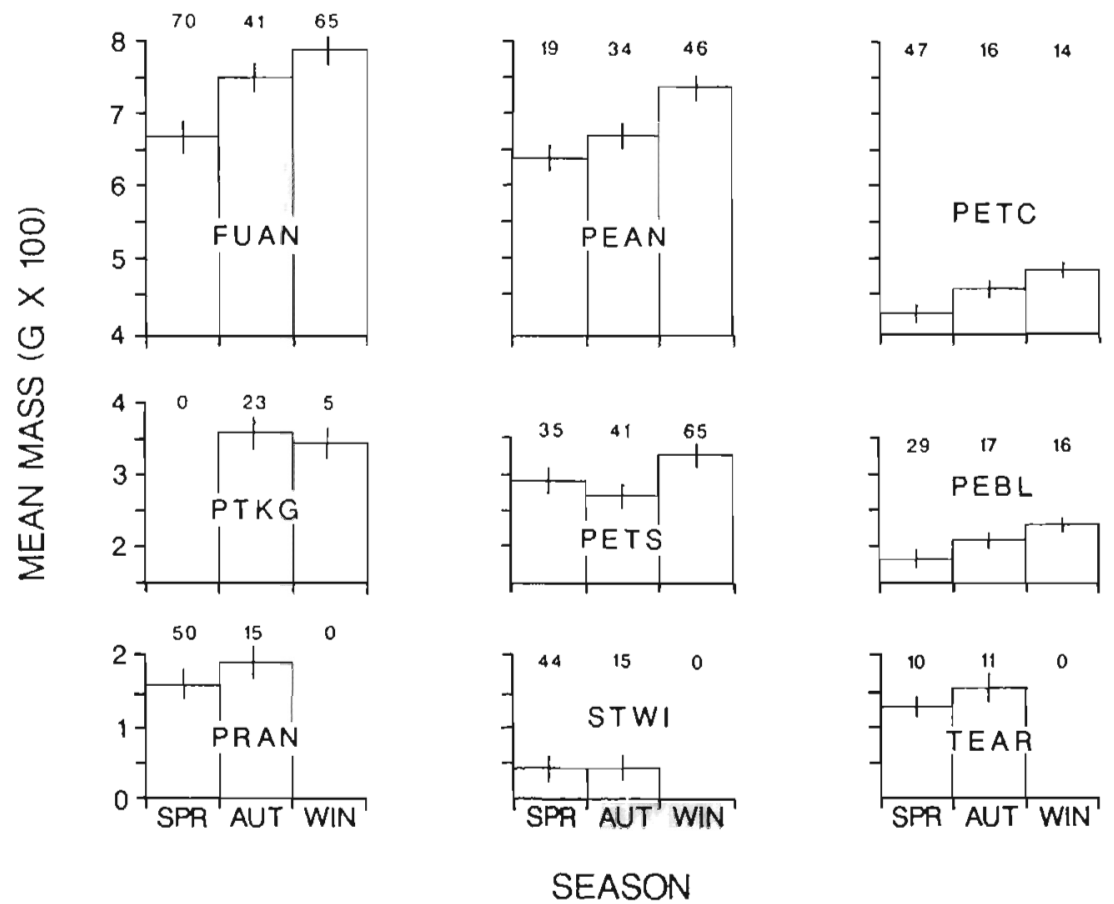

Fig. 7. Comparison of average seabird body mass by season; vertical lines indicate the standard error. (n): number of samples

Table 6. Mean \pm SE mass of reconstituted stomach contents for species sampled within ice-defined habitats. (n): number of samples

\begin{tabular}{|c|c|c|c|c|}
\hline Species & None & $\begin{array}{l}\text { Ice conce } \\
\text { Sparse }\end{array}$ & Heavy & $\mathrm{p}^{a}$ \\
\hline PENE & - & - & $6074 \pm 1247(26)$ & \\
\hline PENA $^{\mathrm{b}}$ & - & $30.2 \pm 3.1$ & $12.5 \pm 7.0(38)$ & 0.05 \\
\hline PETH & $13.0 \pm 5.9(11)$ & $3.3 \quad(1)$ & - & 0.88 \\
\hline FUAN $^{c}$ & $24.4 \pm 7.9(29)$ & $24.8 \pm 9.1(22)$ & $31.2 \pm 13.9(16)$ & 0.25 \\
\hline PEAN $^{b}$ & $25.6 \pm 3.5(54)$ & $20.8 \pm 6.3(32)$ & $48.2 \pm 8.7(30)$ & 0.01 \\
\hline PETC $^{\mathrm{C}}$ & $3.9 \pm 1.1(44)$ & $9.0 \pm 2.8(19)$ & $8.3 \pm 5.0(16)$ & 0.37 \\
\hline PETS $^{b}$ & $21.8 \pm 4.0(32)$ & $32.5 \pm 2.6(111)$ & $29.3 \pm 2.6(111)$ & 0.11 \\
\hline PEBL & $13.9 \pm 2.1(51)$ & $7.2 \pm 2.5(8)$ & $7.2 \pm 2.5$ & 0.33 \\
\hline PRAN & $11.3 \pm 2.0$ & $10.1 \pm 3.1(13)$ & $4.8 \pm 2.2(14)$ & 0.03 \\
\hline PTKG & $18.5 \pm 4.6(25)$ & $0.3 \pm 0.03(3)$ & - & 0.07 \\
\hline STBB & $3.2 \pm 2.2$ & 4.1 (1) & - & 0.77 \\
\hline STWI & $1.7 \pm 0.6(32)$ & $0.7 \pm 0.4(18)$ & $0.2 \pm 0.1(10)$ & 0.04 \\
\hline$T^{T E A R^{b}}$ & 0.0 & $12.0 \pm 3.3(13)$ & $0.2 \pm 0.2$ & 0.03 \\
\hline TEAN $^{b}$ & - & - & $3.4 \pm 1.3$ & - \\
\hline
\end{tabular}


was the average mass of stomach contents. With few exceptions when adequate samples were available. stomach content masses were greatest when the samples were obtained in the usual habitat of respective predators, heavy ice vs open water (Table 6). When controlling for species, the effect on contents mass by habitat, preferred vs avoided, was significant ( $F=5.18$, $\mathrm{df}=1,11 ; p<0.001$ ). Only in the species that exhibit little habitat 'preference', especially the cape petrel and southern fulmar, did we fail to find this pattern. Problematic were patterns for blue and snow petrel and Wilson's storm-petrel, where the trends were consistent with expectation but the differences were not significant. For the blue petrel and the storm-petrel, small sample size in the heavy ice likely effected this analysis. For the snow petrel, other factors may be involved (see 'Discussion').

A pattern supporting the above on feeding success was one showing the proportion of empty stomachs: lowest proportions in the usual (preferred) habitat (Table 1). Cape, blue and Kerguelen petrels, Antarctic prions and Wilson's storm-petrels ate more food and had fewest empty stomachs, i.e. were more successful at foraging, when in the open water than when foraging in the ice. The converse was true for snow and Antarctic petrels, which were practically the only species that did well in both light and heavy ice concentrations. Even the Adélie penguin appeared to fare poorly in the heavy ice.

\section{DISCUSSION}

\section{Basic biological findings}

We detected several general patterns in seabird diet that deserve comment.

Not surprising was the prevalence of fish and larger crustaceans in the diets of snow petrels (Griffiths 1983, Ainley et al. 1984, Ridoux \& Offredo 1989) and Antarctic petrels (Ainley et al. 1984, Klages et al. 1990), of squid and fish in the diet of white-chinned petrels (Prince \& Morgan 1987), of squid and the fish Notolepis coatsi in the diets of emperor penguins (Gales et al. 1990), and the diverse diets of the remaining predators, particularly those for which we had larger samples: Antarctic fulmar, cape petrel and Wilson's storm-petrel (Ainley et al. 1984, Croxall et al. 1988, Ridoux \& Offredo 1989). The diet of Kerguelen petrels had been largely unknown; heretofore, our knowledge was derived from birds breeding in the Subantarctic: 22 samples at Marion Island (data of Schramm in Prince \& Morgan 1987) and 29 samples from Iles Crozet (Jouventin et al. 1988), where the diet was much different from what we observed except that in all localities large decapods were eaten (likely of different species).
Although our sample for southern giant fulmars was small ( $\mathrm{n}=3$ of those having items in their stomachs), their feeding on carrion is consistent with observations elsewhere (Hunter 1983, Ainley et al. 1984). The broad overlap in diets among avian predators is also consistent with results from analyses in bird tissues of stable $\mathrm{C}$ and $\mathrm{N}$ isotopes, as a measure of trophic level (Rau et al. 1992).

One surprise was the great importance of myctophids to the avian predators studied, although earlier we had learned that a number of organisms previously considered by marine biologists to be mesopelagic are taken in abundance by surface-foraging birds (Ainley et al. $1986,1988,1991$, and herein). On the basis of our data, we suggest that the year-round economy of seabirds in pelagic waters of the Weddell Sea is based on myctophids, especially Electrona antarctica, and secondarily krill. Although krill dominated the micronekton community by number and biomass, as measured by the scientific trawling, E. antarctica was the most commonly taken prey and the major source of energy to seabirds. The importance of krill to top trophic level predators in the Southern Ocean appears to have been over-emphasized, although krill is certainly the central prey for many Antarctic seabirds during the chickprovisioning season when the birds are constrained to feed close to shore (reviewed by Croxall 1985). Supporting our observations on the importance of myctophids are several other recently completed studies that have considered the year-round diet of predators (see Adams \& Klages 1987, Croxall \& North 1988, Gartshore et al, 1988, Adams \& Brown 1989, Cooper et al. 1990, Klages et al. 1990). The year-round patterns of food-web structure and trophic level transfer needs to be re-evaluated, because the present perception may be a biased one that could have far-reaching repercussions in other analyses (see Huntley et al. 1991).

Somewhat surprising, although consistent with the importance of fish overall, was the high prevalence of fish in the diet of Antarctic prions. Prevalence was much higher than in other studies of prions (reviewed by Gartshore et al. 1988). If our observations represent more accurately the year-round situation, then our results support Imber's (1981) prediction, on the basis of bill morphology, that Antarctic prions should feed less on smaller prey (especially copepods) than other prions. Studies of diets fed to chicks had only marginally supported Imber's hypothesis. In our study, Antarctic prions ate amphipods to a greater degree than other species and their broad bill might aid in straining out unwanted constituents of salps (i.e. water) with which amphipods are commensal. Blue petrels also ate far more fish than has been reported in studies of breeding birds (see Gartshore et al. 1988).

Initially surprising was the average mass of prey in 
the stomachs of Adélie penguins, which at ca $30 \mathrm{~g}$ was an order of magnitude lower than results from the many studies of adults feeding chicks (see Croxall \& Lishman 1987). The results of our study, however, were similar to those obtained from adult Adélies sampled early in the breeding season (not feeding chicks; Emison 1968, Lishman 1985). Chick-provisioning penguins must eat large meals in order to fast for extended periods between feeding bouts and at the same time must satisfy the nutritional needs of 1 or 2 growing chicks that are only fed once every few days as well. The stomach content masses we observed were consistent with birds having ready access to and a lowered need for food. Nevertheless, reported here are the first samples for Adélies during winter. They fed heavily on krill year-round, but increased the proportion of fish and squid in their diet during winter (see also Ainley et al. 1991).

\section{Diet and habitat choice}

Few studies have compared diets among seabird species in the same habitat. Most previous studies of seabird diets involved samples from breeding individuals who were carrying food to their young, and in these studies, foraging habitat of the predator was inferred only by the type of prey eaten (e.g. Diamond 1984, Adams \& Brown 1989, Ridoux \& Offredo 1989). The over-riding conclusion was that foraging habitat determined diet to a large degree. The present study in the pelagic waters of the Scotia-Weddell Confluence, and one in the neritic waters of the Ross Sea (Ainley et al. 1984), support those conclusions directly by showing a broad overlap in the diets of seabirds foraging in the same habitats and showing changes in diet within the same species when they forage in a different habitat. This was particularly evident in the Ross Sea study where a broader suite of habitats was sampled.

The present study, as in the Ross Sea study, detected only a slight, if any, segregation in diet based on preypredator size in spite of a 1000-fold difference in predator size. Prey size differed as a function of habitat, exemplified by the small size of krill taken by the largest predators - the Adélie and emperor penguins which along with juvenile krill also happen to reside in the pack ice (cf. Ainley et al. 1988, Daly \& Macaulay 1988, Daly 1990). Only at the greatest extremes of prey size, i.e. the very largest squid eaten by the large emperor penguins and the tiny amphipods eaten most frequently by the smallest petrels, was there any possibility that predator size affected prey selection. However, the trend was not strong enough that one could conclude that habitat-related prey size constrained any predators to one habitat or another.
The over-riding similarity in the size and species composition among predators diets in this study, in spite of the predators distinct habitat preferences in the marginal ice zone, indicates that Antarctic birds do not choose foraging habitats on the basis of the availability of particular prey species (see also Ainley et al. 1984, Ainley et al. 1991). Bird species of the open-water and the pack-ice assemblages ate the same prey in similar proportions regardless of year or season. Furthermore, any prey-predator size patterns were not consistent across all members of any one species assemblage. We did, however, see that members of the 2 assemblages foraged more successfully when they resided in their usual habitat (i.e. pack-ice species caught more prey when foraging in the pack ice than in the open water and vice versa for the open-water species). This study represents the first time such a comparison and analysis of foraging success vs habitat has been attempted for seabirds. Though pack-ice species remained during winter, they apparently foraged with ease in waters affected by pack-ice, as indicated by their robust fat deposits. To be sure, other factors can also contribute to seasonal changes in body mass (see Lima 1986).

One question remaining is why species without specialized foraging behaviors avoid and do poorly in the pack-ice environment (Ainley et al. unpubl, data). The answer appears to be clear but requires more opportunity for observation. Snow and Antarctic petrels apparently have specialized foraging techniques that the open-water species do not exhibit (ambush feeding and pursuit plunging, respectively), which would allow predation on quicker and larger prey. Emperor penguins can remain submerged longer than any bird (Kooyman \& Ponganis 1990), an ability that should facilitate foraging beneath ice floes. Finally, Adélie penguins submerge for a much shorter period but one that is longer (or at least deeper) than their open-water, ecologically-equivalent congener, the chinstrap penguin (Whitehead 1989).

Another question is why the pack-ice species prefer to stay in the pack ice even during winter when most of the open-water (mostly migratory) species have either left the Antarctic entirely or major portions of their respective populations have done so and in the process have left vacant the open water adjacent to the ice (Ainley et al. unpubl. data). As mentioned in the 'Introduction', this phenomenon is not unique to these 2 assemblages of vertebrates. The question for the Antarctic avifauna is answerable by the fact that many more feeding opportunities are present in the pack ice during winter, where the presence of ice and the compression of productivity to the very surface (and principally within the ice floes themselves) renders grazing micronekton more vulnerable to predation by surface- 
foraging predators (Griffiths 1983, Ainley et al. 1986, Ainley et al. 1991). The high fat levels attained by winter, pack-ice foraging species are evidence for feeding success. All a predator would need are the specialized feeding techniques required to exploit the opportunities. Moreover, food availability appears to decrease dramatically at the surface in open water during winter compared to spring (Ainley et al. 1991). This would discourage predators from remaining in the open-water habitat during winter. Within the upper $200 \mathrm{~m}$ of open waters, there was little variation in prey abundance (not necessarily availability) between spring, autumn and winter (Lancraft et al. 1989, 1991), but little of that depth range is accessible to the bird species sampled, with the exception of the penguins.

It is likely that availability of prey at the very surface is important in prey selection, as discussed by Ainley et al. (1991). Diets of pack-ice species and of open-water species that remain during winter in appreciable numbers (Ainley et al. unpubl. data) did not correlate to prey availability as determined by trawls; correlations were significant for species that seasonally leave the Antarctic. Except for the Adélie Penguin, the pack-ice, year-round resident predators took more of the rarer, faster but larger (and therefore, more energy-rich) micronekton than micronekton species that appeared in the trawls. This meant an avoidance by the birds of the small crustaceans (including adult krill) and salps, which have lesser food value per item (e.g. Huntley et al. 1989). The comparison was somewhat artificial, however, because some of the most important prey, especially squid and other highly mobile micronekton such as Notolepis coatsi, were not caught effectively by the trawls (see also Ainley et al. 1991). Another prey species numerically important in diets was the amphipod Vibilia antarctica, which also was apparently not adequately sampled by the trawls. This species may have occurred right at the surface where the trawls did not sample. While the comparison between bird diets and trawls did not yield entirely clear results, this was the first time such a comparison has ever been attempted and it did provide interesting results.

Pack-ice species may feel out of place in the open water (Wiens 1989, p. 283), and the high availability of prey in the ice-covered waters would provide little incentive to investigate feeding opportunities elsewhere. Indeed, prey availability apparently increased in the pack ice during the winter (Ainley et al. 1991). Problematic is the snow petrel, a species that is closely associated with ice (Griffiths 1983, Ainley et al. 1984, Ainley et al. unpubl. data), but which appears to forage more successfully in the open water adjacent to the ice than do other ice species. Although the average stomach contents weight was lower in open water, a population difference could not be inferred due to the high variance. Several reasons for the observed pattern are possible. For yet unexplainable reasons, our sampling of snow petrels may have been more affected than that of other species by our use of cod liver oil to attract birds to the collecting site. Although species differences in olfactory ability have not been tested in the Antarctic, all petrels can smell a fish slick from long distances (e.g. Jouventin \& Robin 1984), and thus to some degree, the habitat in which we made collections was perhaps not the one in which the birds collected were foraging. The snow petrel has one of the largest olfactory-bulb-size-to-brain-size ratios of any bird (Bang \& Cobb 1968), which is consistent with its life style (see Bang 1966, Healy \& Guilford 1990). Furthermore, a fish slick may have been more meaningful to snow petrels perhaps because they feed more on fish than any other ice species (see Rau et al. 1992). Finally, the snow petrel is one of those species attracted to ice bergs (see Ainley et al. 1984) and perhaps this is not a reflex attraction to ice but rather demonstrates feeding opportunities yet unknown to us. The deep draft of a berg induces upwelling and turbulence in its wake, which in turn is produced by the rapid movement of wind-driven surface waters relative to the slow movement of the berg (Jacobs 1992). Such phenomena could bring prey to the surface. Our category of open water included the presence of ice bergs. If this scenario is the case then the data from this study suggest that snow petrels may be able to exploit the ice berg opportunities as well as can the open-water species.

Our results in the Scotia-Weddell Confluence, considered along with those from studies in the Bering Sea (e.g. Schneider \& Hunt 1982, Schneider et al. 1986, Springer et al. 1987) and elsewhere (Haney \& McGillivary 1985, Haney 1986a, b), indicate that the availability of prey, and particularly the means and rate by which prey become available, and not so much the type of prey, has a strong bearing on the structure of pelagic seabird faunas. Our study has shown that both physical and biological factors play a role in community structure among avian predators within the marginal ice zone of the Scotia-Weddell Confluence.

Acknowledgements. We appreciate the ideas garnered through discussions with our AMERIEZ colleagues, especially J. Torres, T. Hopkins and T. Lancraft. L. A. Ferris, E. F. O'Connor, R. L. Pitman, L. B. Spear, and G. Wallace assisted in data collection and sample reduction. Personnel of the U.S. Antarctic Program and the crews of RV 'Melville', MV 'Polar Duke' and USCGC 'Westwind' and 'Glacier' assisted in logistics. L. B. Spear provided valuable assistance with and comments on the manuscript. Useful technical criticisms were also provided by P. Adamus, G. L. Hunt, D. N. Schneider, and E. Woehler; $M$. Bollman provided an editorial review and D. Coffey a QA/QC review. D. J. Rugg ran the StatXact program. The project was funded by NSF grants DPP 8304815 
and 8419894 . The data analysis was funded in part by the EPA, and the manuscript has been subjected to and approved by the EPA's peer and administrative (QA/QC) review. This is contribution number 523 of the Point Reyes Bird Observatory.

\section{LITERATURE CITED}

Adams, N. J., Brown, C. R. (1989). Dietary differentiation and trophic relationships in the sub-Antarctic penguin community at Marion Island. Mar. Ecol. Prog. Ser. 57: 249-258

Adams, N. J., Klages, N. T. (1987). Seasonal variation in the diet of the king penguin (Aptenodytes patagonicus) at subAntarctic Marion Island. J. Zool., Lond. 212: 303-324

Ainley, D. G., Boekelheide, R. J. (1983). An ecological comparison of oceanic seabird communities of the South Pacific Ocean. Stud. Avian Biol. 8: 2-23

Ainley, D. G., Boekelheide, R. J. (1990). Seabirds of the Fara)lon Islands: ecology, dynamics and structure of an upwelling-system community. Stanford Univ. Press, Stanford

Ainley, D. G., Fraser, W. R., Daly, K. L. (1988). Effects of pack ice on the composition of micronektonic communities in the Weddell Sea. In: Sahrhage, D. (ed.) Antarctic ocean and resources variability. Syringer-Verlag. Berlin, p. 140-146

Ainley, D. G., Fraser, W. R., Smith, W. O., Hopkins, T. L., Torres, J. J. (1991). The structure of upper level pelagic food webs in the Antarctic: effect of phytoplankton distribution. J. mar. Syst. 2: 111-122

Ainley, D. G., Fraser, W. R., Sullivan, C. W., Torres, J. J., Hopkins, T. L., Smith, W. O. (1986). Antarctic mesopelagic micronekton: evidence from seabirds that pack ice affects community structure. Science 232: 847-849

Ainley, D. G., O'Connor, E. F., Boekelheide, R. J. (1984). The marine ecology of birds in the Ross Sea, Antarctica. Amer. Ornithol. Union, Monogr. 32, Washington, D.C

Ainley, D. G., Sullivan, C. W. (1984). AMERIEZ 1983: a summary of activities on board R/V Melville and USCGC Westwind. Antarc. J. U.S. 19(5): 100-102

Ainley, D. G., Sullivan, C. W. (1989). A summary of a winter cruise of the Weddell and Scotia seas on Polar Duke. Antarc. J. U.S. 24(5): 144-147

Bang, B. G. (1966). The olfactory apparatus of tubenosed birds (Procellariiformes). Acta Anatomica 65: 391-415

Bang, B. G., Cobb, S. (1968). The size of the olfactory bulb in 108 species of bird. Auk 85: 55-61

Conover, W. J. (1980). Practical nonparametric statistics, 2nd edn. John Wiley \& Sons, Inc., New York

Cooper, J., Brown, C. R., Gales, R. P., Hindell, M. A., Klages, N. T. W., Moors, P. J., Pemberton, D., Ridoux, V., Thompson, K. R., Van Heezik, Y. M. (1990). Diets and dietary segregation of crested penguins (Eudyptes). In: Davis, L. S., Darby, J. T. (eds.) Penguin biology. Academic Press, London, p. 131-156

Croxall, J. P. (1985). Seabirds. In: Laws, R. M. (ed.) Antarctic ecology, Vol. 2. Academic Press, London, p. 533-618

Croxall, J. P., Lishman, G. S. (1987). The food and feeding ecology of penguins. In: Croxall, J. P. (ed.) Seabirds: feeding ecology and role in marine ecosystems. Cambridge Univ. Press, Cambridge, p. 101-134

Croxall, J. P., North, A. W. (1988). Fish prey of Wilson's Storm Petrel Oceanites oceanicus at South Georgia. Br. Antarc. Surv. Bull. 78: 37-42

Croxall, J. P., Hill, H. J., Lidstone-Scott, R., O'Connell, M. J., Prince, P. A. (1988). Food and feeding ecology of Wilson's storm petrel Oceanites oceanicus at South Georgia. J. Zool., Lond. 216: 83-102
Daly, K. (1990). Overwintering development, growth and feeding of larval Euphausia superba in the Antarctic marginal ice zone. Limnol. Oceanogr. 35: 1564-1576

Daly, K. L., Macaulay, M. C. (1988). Abundance and distribution of krill in the ice edge zone of the Weddell Sea, austral spring 1983. Deep Sea Res. 35(1): 21-41

Diamond, A. W. (1984). Feeding overlap in some tropical and temperate seabird communities. Stud. Avian Biol. 8: 24-46

Duffy, D. C., Jackson, S. (1986). Diet studies of seabirds: a review of methods. Colonial Waterbirds 9: 1-17

Emison, W. B. (1968). Feeding preferences of the Adélie penguin at Cape Crozier, Ross Island. Antarc. Res. Ser. 12: $191-212$

Feinberg, S. E. (1980). The analysis of cross-classified categorical data, 2nd edn. The MIT Press, Cambridge, MA

Fraser, W. R., Ainley, D. G. (1986). Ice edges and seabird occurrence in Antarctica. BioScience 36: 258-263

Gales, N. J., Klages, N. T. W., Williams, R., Woehler, E. J (1990). The diet of the emperor penquin, Aptenodytes forsteri, in Amanda Bay, Princess Elizabeth Land, Antarctica. Antarc. Sci. 2(1): 23-28

Gartshore, N. A., Steele, W. K., Klages, N. T. W. (1988) Summer diet of the Salvin's prion at sub-Antarctic Marion Island. S. Afr. J. Zool. 23(4): 309-313

Griffiths, A. M. (1983). Factors affecting the distribution of the Snow Petrel (Pagodroma nivea) and the Antarctic Petrel (Thalassoica antarctica). Ardea 71: 145-150

Haney, J. C. (1986a). Seabird segregation at Gulf Stream frontal eddies. Mar. Ecol. Prog. Ser. 28: 279-285

Haney, J. C. (1986b). Seabird patchiness in tropical oceanic waters: the influence of Sargassum 'reefs'. Auk 103: $141-151$

Haney, J. C., McGillivary, P. A. (1985). Midshelf fronts in the South Atlantic Bight and their influence on seabird distribution and seasonal abundance. Blol. Oceanogr. 3(4): $401-430$

Healy, S., Guilford, T. (1990). Olfactory-bulb size and nocturnality in birds. Evolution 44:339-346

Horn, H. S. (1966). Measurement of 'overlap' in comparative ecological studies. Am. Nat. 100: 419-424

Hunt, G. L. Jr, Schneider, D. C. (1987). Scale-dependent processes in the physical and biological environment of marine birds. In: Croxall, J. P. (ed.) Seabirds: feeding ecology and role in marine ecosystems. Cambridge Univ. Press, Cambridge, p. 7-42

Hunter, S. (1983). The food and feeding ecology of the giant petrels Macronectes halli and $M$. giganteus at South Georgia. J. Zool., Lond. 200: 521-538

Huntley, M. E., Sykes, P. F., Marin, V. (1989). Biometry and trophodynamics of Salpa thompsoni Foxton (Tunicata: Thalicacea) near the Antarctic Peninsula in austral summer, 1983-1984. Polar Biol. 10: 59-70

Huntley, M. E., Lopez, M. D. G., Karl, D. M. (1991). Top predators in the Southern Ocean: a major leak in the biological carbon pump. Science 253: 64-66

Husby, D. M., Meunch, R. D. (1988). Hydrographic observations in the northwestern Weddell Sea Marginal Ice Zone during March 1986. U.S. Natl. Ocean. Atmos. Admin., Tech. Memo. No. NOAA-TM-NMFS-SWFC-106, La Jolla, CA

Husby, D. M., Meunch, R. D., Gunn, J. T. (1989). Oceano graphic observations in the Scotia Sea Marginal Ice Zone, June-August 1988. U.S. Natl. Ocean. Atmos. Admin., Tech. Memo. No. NOAA-TM-NMFS-SWFC-127, La Jolla, CA

Imber, M. J. (1981). Diets of storm petrels Pelagodroma and Garrodia and of prions Pachyptilla (Procellariformes): 
ecological separation and bill morphology. In: Cooper, J. (ed.) Proc. Symp. Birds of the Sea and Shore. Afr. Seabird Group, Cape Town, p. 63-88

Jacobs, S. S. (1992). The voyage of iceberg B-9. Am. Sci. 80: $32-42$

Jouventin, P., Ridoux, V., Stahl, J.-C., Weimerskirch, H. (1988). La ségrégation écologique des pétrels des lles Crozet. Rev. Ecol. (Terre Vie) 43: 357-366

Jouventin, P., Robin, J. P. (1984). Olfactory experiments on some Antarctic birds. Emu 84: 46-48

Kaufman, L., Rousseeuw, P. J. (1990). Finding groups in data. John Wiley \& Sons, New York

Keast, A., Morton, D. S. (eds.) (1980). Migrant birds in the Neotropics: ecology, behavior, distribution, and conservation. Smithsonian Inst., Washington, D.C.

Klages, N. T. W. (1989). Food and feeding ecology of emperor penguins in the eastern Weddell Sea. Polar Biol. 9: 385-390

Klages, N. T. W., Gales, R., Pemberton, D. $\{1990\}$. The stomach contents of Antarctic Petrels Thalassoica antarctica feeding young chicks at Scullin Monolith, Mawson Coast, Antarctica. Polar Biol. 10: 545-547

Kooyman, G. L., Ponganis, P. J. (1990). Behavior and physiology of diving emperor and king penguins. In: Davis, L. S., Darby, J. T. (eds.) Penguin biology. Academic Press, London, p. 229-242

Lancraft, T. M., Torres, J. J., Hopkins, T. L. (1989). Micronekton and macrozooplankton in the open waters near Antarctic ice edge zones (AMERIEZ 1983 and 1986). Polar Biol. 9: 225-233

Lancraft, T. M., Hopkins, T. L., Torres, J. J., Donnelly, J. (1991). Oceanic micronektonic/macrozooplanktonic community structure and feeding in ice covered Antarctic waters during the winter. Polar Biol. 11: 157-167

Lishman, G. S. (1985). The food and feeding ecology of Adelie penguins (Pygoscelis adeliae) and chinstrap penguins $(P$. antarctica) at Signy Island, South Orkney Islands. J. Zool., Lond (A) 205: 245-263

Lima, S. L. (1986). Predation risk and unpredictable feeding conditions: determinants of body mass in birds. Ecology 67: $377-385$

Magurran, A. E. (1988). Ecological diversity and its measurement. Princeton Univ. Press, Princeton, NJ

Mehta, C., Patel, N. (1992). StatXact statistical software for exact nonparametric inference. Cytel Software Corp., Cambridge, MA

Meunch, R. D., Gunn, J. T., Husby, D. M., Huber, B. A., Mountain, D. G. (1992). The Weddell-Scotia marginal ice zone: physical oceanographic conditions, geographical and seasonal variability. J. mar. Syst. 3: 169-182

Montague, T. L. (1984). The food of Antarctic petrels Thalassoica antarctica. Emu 84: 244-245

Murphy, R. C. (1936). Oceanic birds of South America. Macmillan, New York

This article was submitted to the editor
Nie, N., Hull, D. H., Jenkins, J. C., Steinbrenner, K., Brent, D. H. (1970). Statistical package for the social sciences, 2nd edn. McGraw-Hill, New York

Norusis, M. J. (1986). SPSS/PC+ advanced statistics. SPSS, Inc., Chicago, IL

Offredo, C., Ridoux, V. (1986). The diet of emperor penguins Aptenodytes forsteri in Adélie Land, Antarctica. Ibis 128: 409-4.13

Prince, P. A. (1980). The food and feeding ecology of blue petrel (Halobaena caerulea) and dove prion (Pachyptilla desolata). J. Zool., Lond. 190: 59-76

Prince, P. A., Morgan, R. A. (1987). Diet and feeding ecology of procellariiformes. In: Croxall, J. P. (ed.) Seabirds: feeding ecology and role in marine ecosystems. Cambridge Univ. Press, Cambridge, England, p. 135-171

Rau, G. H., Ainley, D. G., Bengtson, J. L., Torres, J. J, Hopkins, T. L. (1992). $15 \mathrm{~N} / 14 \mathrm{~N}$ and $13 \mathrm{C} / 12 \mathrm{C}$ in Weddell Sea birds, seals, and fish: implications for diet and trophic structure. Mar. Ecol. Prog. Ser. 84: 1-8

Ricklefs, R. E., Day, C. H., Huntington, C. E., Williams, J. B. (1985). Variability in feeding rate and meal size of Leach's storm-petrel at Kent Island, New Brunswick. J. Anim. Ecol. 54: 883-898

Ridoux, V., Offredo, C. (1989). The diets of five summer breeding seabirds in Adélie Land, Antarctica. Polar Biol. 9 : $137-145$

Schneider, D., Hunt, G. L. Jr. (1982). Carbon flux to seabirds in waters with different mixing regimes in the southeastern Bering Sea. Mar. Biol. 67: 337-344

Schneider, D., Hunt, G. L. Jr., Harrison, N. M. (1986). Mass and energy transfer to seabirds in the southeastern Bering Sea. Cont. Shelf Res. 5: 241-257

Seber, G. A. F. (1984). Multivariate observations. John Wiley \& Sons, New York

Springer, A. M., Murphy, E. C., Roseneau, D. G., McRoy, C. P., Cooper, B. A. (1987). The paradox of pelagic food webs in the northern Bering Sea -1 . Seabird food habits. Cont. Shelf Res. 7: 895-911

Sullivan, C. W., Ainley, D. G. (1987). AMERIEZ 1986: a summary of activities on board the R/V Melville and USCGC Glacier. Antarc. J. U.S. 22(5): 167-169

Volkman, N. J., Presler, P., Trivelpiece, W. (1980). Diets of pygoscelid penguins at King George Island, Antarctica. Condor 82: 373-378

Watson, G. E. (1975). Birds of the Antarctic and Subantarctic. Amer. Geophys. Union, Washington, D.C.

Whitehead, M. D. (1989). Maximum diving depths of the Adélie penguin, Pygoscelis adeliae, during the chick rearing period, in Prydz Bay, Antarctica. Polar Biol. 9: 329-332

Wiens, J. (1989). The ecology of bird communities. Cambridge Univ. Press, Cambridge

Wilson, R. P. (1984). An improved stomach pump for penguins and other seabirds. J. Field Ornithol. 55: 109-112

Manuscript first received: April 29, 1992

Revised version accepted: September 4, 1992 